\title{
Effect of Organic and Mineral Nitrogen Sources with and without Rhizobium Inoculation on Growth and Yield of Common Bean Plant Using ${ }^{15} \mathrm{~N}$ Tracer Technique
}

\author{
Fatma M. A. Ghaly ${ }^{1}$; M. A. Soliman ${ }^{1}$; A. A. Moursy ${ }^{2}$; M. M. Ismail ${ }^{2}$ and
} M. M. A. Elshayeb ${ }^{1}$

${ }^{1}$ Faculty of Agriculture, Damietta University, Egypt.

${ }^{2}$ Atomic Energy Authority, Nuclear Research Center, Soil and Water Research Department, Abou-Zaabl, 13759, Egypt

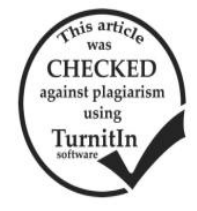

\begin{abstract}
A Field experiment was conducted to follow up the effect of-organic - and/or mineral $\mathrm{N}$ fertilizer either solely or in combinations on seed yield of common bean plant grown on sandy soil using ${ }^{15} \mathrm{~N}$ tracer technique. The experimental design was a Factorial Complete Randomized Block Design (FCRBD) - and treatments were replicated three times. Each experimental plot (10m2) received different proportions of organic and / or mineral N fertilizer up to $100 \% \mathrm{~N}$ in presence or absence of rhizobium inoculants. Results indicated the enhancement of seed yield and $\mathrm{N}$ uptake by bacterial inoculation. The overall averages of organic sources revealed the superiority of quite manure over leuceana residues followed by compost treatment. Absolute values of Ndff, Ndfs + Ndfo and Ndfa were frequently affected by portions of chemical and organic additives whereas Ndff tended to increase with increasing $\mathrm{N}$ fertilizer rate. Adversely, Ndfa was negatively affected by increasing $\mathrm{N}$ rate. Organic additives enhanced the portions of Ndff and Ndfs $+\mathrm{Ndfo}$. This holds true with and without Rhizobium inoculation. These portions were markedly increased as affected by the addition of quite manure mixed with moderate $\mathrm{N}$ fertilizer rate $(50 \%$ Chem- $\mathrm{N}+50 \%$ quite manure- $\mathrm{N})$. Low to moderate quantities of chemical fertilizer in combination with organic additives had enhanced the utilization of chemical-N source comparing to the full chemical fertilized plants.
\end{abstract}

Keywords: Common bean, Rhizobium, Sandy soil, ${ }^{15} \mathrm{~N}-$ Urea fertilizer, Organic compost

\section{INTRODUCTION}

Importance of common bean as an economical vegetable crop has a nutritional value for human and considered main source of protein was reported earlier (CIAT 2001; Broughton et al. 2003).

Realistic use of nitrogen by common bean indicates its gluttonous for $\mathrm{N}$ fertilizer that may negatively affect the nodule formation and inhibited the biological nitrogen fixation process while low adequate additions may enhanced the process (Brito et al. 2011, Soares et al., 2006; Souza et al. 2011).

Meanwhile, due to the high cost of manufactured chemical fertilizers (Ngetich et al. 2012; Fukuda et al. 2012), BNF could be considered as low or cheap cost effective way to compensate $\mathrm{N}$ for legumes (Belane and Dakora 2009, 2010; Naab et al.2009; Nyemba and Dakora 2010; Sprent et al. 2010; Pule-Meulenberg et al. 2010; Mohale et al.2014). In addition, it improves crop yield and replenish soil $\mathrm{N}$ budget (Maina et al. 2011).

In this respect, Rhizobium leguminosarum biovar phaseoli inoculants widely applied in common bean cultivation to meet plant growth and grain yield (Kellman et al. 2005, Kabahuma 2013, Akhter et al. 2014; Tabaro 2014). One of the most accurate methods for BNF estimation is the use of ${ }^{15} \mathrm{~N}$ tracer technique (Bambara and Ndakidemi 2010 a,b, Nyemba and Dakora 2010).

Thus, this study aimed at following the performance of different $\mathrm{N}$-fertilizers with or without Rhizobium inoculation in improving yield of common bean crop.

\section{MATERIALS AND METHODS}

Field experiment was carried out at; experimental farm of Soils and Water Research Department, Nuclear Research Center, Atomic Energy Authority, Inshas, Egypt. Materials:

Experimental soil:

Experimental site is located in Inshas, Sharkia Governorate. For analysis, soil samples were collected from $0-15 \mathrm{~cm}$ depth layer. The Soil samples were air dried ground and sieved to pass through a $2 \mathrm{~mm}$ sieve. Some physical and chemical characteristics of the experimental soil are presented in Table (1).

Table 1. Some physical and chemical properties of experimental soil.

\begin{tabular}{|c|c|}
\hline Property & Value \\
\hline \multicolumn{2}{|c|}{ Particle size distribution (\%) } \\
\hline Coarse sand & 64.1 \\
\hline Fine sand & 26.4 \\
\hline Clay & 6.8 \\
\hline Silt & 2.7 \\
\hline Soil Texture & Sand \\
\hline $\mathrm{pH}(1: 2.5$ paste $)$ & 7.97 \\
\hline E.C. $\left(\mathrm{ds} \mathrm{m}^{-1}\right)$ & 0.27 \\
\hline Total N $(\%)$ & 0.007 \\
\hline \multicolumn{2}{|c|}{ Cations (meq $100 \mathrm{~g}^{-1}$ soil) } \\
\hline $\mathrm{Ca}$ & 1.25 \\
\hline $\mathrm{Mg}$ & 1.00 \\
\hline $\mathrm{Na}$ & 0.32 \\
\hline $\mathrm{K}$ & 0.09 \\
\hline \multicolumn{2}{|c|}{ Anion (meq $100 \mathrm{~g}^{-1}$ soil) } \\
\hline $\mathrm{SO}_{4}^{-}$ & 0.53 \\
\hline $\mathrm{CO}_{3}^{--}$ & 0.00 \\
\hline $\mathrm{HCO}_{3}^{-}$ & 0.88 \\
\hline $\mathrm{Cl}^{-}$ & 1.25 \\
\hline
\end{tabular}

Plant seeds: Seeds of common bean cultivar (Phaseolus vulgaris L. Giza 6) was kindly provided by the Agriculture Research Centre (ARC), Giza, Egypt.

Organic fertilizers:

Organic manure sources: Leucaena residues and quite manure were locally supplied.

Composting manure: The organic compost used in this experiment was prepared by composting a mixture of organic manures (1) [cattle + poultry +goat] + plant residues (2) [wheat + barley + chickpeas + lupine straw]. The mixture consists of half $(1)+$ half (2). To enhance composting $2 \mathrm{~kg}$ ammonium sulphate $+2 \mathrm{~kg}$ of agricultural sulphur $+2 \mathrm{~kg} \mathrm{Ca}$-super phosphate were added to each $\mathrm{m}^{3}$ of residues. Composting process was carried out according to Moursy, (2008). 
Table 2. Some chemical characteristics of-used organic materials.

\begin{tabular}{lccc}
\hline \multirow{2}{*}{ characteristic } & \multicolumn{3}{c}{ Organic materials } \\
\cline { 2 - 4 } & Compost & $\begin{array}{c}\text { Luciana } \\
\text { residues }\end{array}$ & $\begin{array}{c}\text { Quite } \\
\text { manure }\end{array}$ \\
\hline $\mathrm{pH}(1: 2.5$ water) & 6.70 & 6.89 & 6.14 \\
$\mathrm{E} . \mathrm{C} .\left(\mathrm{dSm} \mathrm{Sm}^{-1}\right) 1: 1$ extract & 12.70 & 10.50 & 12.3 \\
Total N g kg-1 & 28.3 & 40.9 & 16.3 \\
Total P g kg & 8.4 & 17.8 & 19.1 \\
Total K g kg-1 & 6.9 & 8.0 & 9.66 \\
C/N ratio & 12.6 & 13.1 & 15.3 \\
Organic matter \% & 57.02 & 59.00 & 43.10 \\
\hline
\end{tabular}

\section{Nitrogen-Fixing Bacteria:}

Rhizobium leguminosarum biovar phasolii was provided by the Microbiology Department, Soils, Water and Environment Institute, Agricultural Research Center, Giza, Egypt.

Chemical fertilizer:

N-labeled urea $\left(5 \%{ }^{15} \mathrm{~N}\right.$ atom excess) was applied in equal the doses; the first was three weeks after planting while the second was two weeks after the first one dose.

Experimental treatments and design:

Experimental treatments were randomly arranged as follows:

$1-100 \%$ Urea $-\mathrm{N}$ as a control.

$2-75 \%$ Urea $-\mathrm{N}+25 \%$ Org $-\mathrm{N}$.

3- $50 \%$ Urea $-\mathrm{N}+50 \%$ Org $-\mathrm{N}$.

4- $25 \%$ Urea $-\mathrm{N}+75 \%$ Org $-\mathrm{N}$.

5- $100 \%$ Org - N.

Experimental layout:

The experiment was carried out under drip irrigation system on sandy soil. The area of each plot was $10 \mathrm{~m}^{2}(9.0 \times 1.11)$ and spacing of $10-15 \mathrm{~cm}$ between plants inter-row and $55 \mathrm{~cm}$ between rows. Fertilization treatments were arranged with and without bacterial inoculation. All treatments were replicated three times. Common Bean (Phaseplus vulgaris L. Giza 6) seeds were planted at 18 February 2016. Nitrogen fertilizer was applied at rate of $60 \mathrm{~kg} \mathrm{~N}^{-\mathrm{N}^{-1}}$ (equal to $143 \mathrm{~g} \mathrm{~N}$ per plot) either added solely or in combination with organic-N. Were thoroughly incorporated into the soil four weeks before sowing. Afterwards, the soil was lightly irrigated to establish good microbial activity for decomposing leucaena residues. Quite manure was applied three weeks before sowing Compost was thoroughly incorporated with into the soil two weeks before sowing. All plots were basically fertilized with $80 \mathrm{~kg} \mathrm{P}^{-1}$ as super phosphate $6.8 \% \mathrm{P}$ and $50 \mathrm{~kg} \mathrm{~K}$ fed $^{-1}$ as potassium sulphate $40 \% \mathrm{~K}$. Recommended potassium fertilizer rate was splitted into three equal portions added at 15, 30, and 45 days after sowing while super-phosphate was added once before sowing.

\section{Methods of analysis:}

Chemical and physical analyses of experimental soil samples were determined according Carter and Greogrich (2008).

Chemical analyses were of plant samples were carried out according to Estefan et al., (2013).

\section{${ }^{15} \mathrm{~N}$ isotopes dilution technique:-}

Isotope dilution concept and standard equations were used for quantifying nitrogen derived from fertilizer (Ndff\%), from soil ( $\mathrm{Ndfs} \%$ ), from air $(\mathrm{Ndfa} \%$ ) and nitrogen use efficiency (NUE\%) which recovered by seed plants according to Training Course series No 14, IAEA (2001)

\section{Statistical analysis:}

The analysis of variance for the final data was assayed using the system ANOVA and the values L.S.D from the controls were calculated at 0.05 levels according to SAS (1987).

\section{RESULTS AND DISCUSSION}

\section{Seed yield $\left(\mathrm{g} \mathrm{plot}^{-1}\right)$}

Seed yield was significantly fluctuated as affected by fertilization treatments and bacterial inoculation (Table $3)$. The highest values of seed yield were observed with $100 \%$ quite manure as will as $25 \%$ Min $-\mathrm{N}+75 \%$ Leucaena residues under inoculated plants ;which relatively increased by about $27.1 \%$. Over the fully chemical fertilized treatment $(100 \%$ urea- N On the other hand, the lowest value was detected with the uninoculated plants treated with $50 \%$ Min- $\mathrm{N}+50 \%$ compost-N which relatively decreased by about $55.4 \%$ under those fully fertilized with urea-

Table 3. Effect of fertilization treatments on seed yield of common bean in the presence or absence of bacterial inoculation.

\begin{tabular}{|c|c|c|c|c|c|c|}
\hline \multirow{3}{*}{$\begin{array}{l}\text { Treatments } \\
\text { \%Min + \%Org. }\end{array}$} & \multicolumn{6}{|c|}{ Seeds $\left(\right.$ g plot $\left.^{-1}\right)$} \\
\hline & \multicolumn{6}{|c|}{ Organic Additives } \\
\hline & Inocu. & untreated & Leucaena residues & Compost & Quite manure & Mean \\
\hline \multirow{2}{*}{$0+100$} & Inoc & - & 405.00 & 395.00 & 410.00 & 348.89 \\
\hline & unInoc & - & 243.33 & 231.67 & 348.33 & 328.89 \\
\hline Mean & & & 324.2 & 313.3 & 379.2 & 338.9 \\
\hline \multirow{2}{*}{$25+75$} & Inoc & - & 383.33 & 345.00 & 236.66 & 309.99 \\
\hline & unInoc & - & 210.00 & 190.00 & 201.66 & 212.22 \\
\hline Mean & & & 296.7 & 267.5 & 219.2 & 261.1 \\
\hline \multirow{2}{*}{$50+50$} & Inoc & - & 303.33 & 376.66 & 375.00 & 336.33 \\
\hline & unInoc & - & 257.33 & 183.33 & 373.33 & 286.66 \\
\hline Mean & & & 280.3 & 280.0 & 374.2 & 311.5 \\
\hline \multirow{2}{*}{$75+25$} & Inoc & - & 410.00 & 290.00 & 358.33 & 352.78 \\
\hline & unInoc & - & 355.00 & 186.66 & 316.66 & 286.11 \\
\hline$\overline{\text { Mean }}$ & & & 382.5 & 238.3 & 337.5 & 319.4 \\
\hline Averages & & & 320.9 & 274.8 & 327.5 & \\
\hline \multirow{2}{*}{$100+0$} & Inoc & 322.67 & & & & \\
\hline & unInoc & 411.00 & & & & \\
\hline
\end{tabular}

\section{L.S.D At $5 \%$}

Analysis of Variances With and without Inoculation

Organic Materials (A).71 : $\quad 124.50 \quad 73.71$

$\begin{array}{lll}\text { Nitrogen (B) : } & 106.30 & 62.96\end{array}$

$\begin{array}{lrr}\text { A x B : } & 141.60 & 83.84\end{array}$

Mean averages, despite of inoculation,-indicated the superiority of fully organic treated plant over those received $75 \%$ urea $+25 \%$ organic followed by $50 \%$ urea plus $50 \%$ organic the those of $25 \%$ urea plus $75 \%$ organic. The overall averages of organic sources revealed the superiority of quite manure over leuceana residues followed by compost treatment. 
Generally, inoculated plants produced higher seed yield than the un-inoculated ones. These findings are in harmony with those obtained by Adeyeye, et.al, (2017), who proved that inoculation improved the seed yield of soybean. Similar findings were reported for peanut (Nabil et al., 2015), and common bean production (Hungria et al., 2003) at low rates of $\mathrm{N}$ applied with Rhizobium inoculation.

$\mathrm{N}$ uptake by seeds $\left(\mathrm{g} \mathrm{plot}^{-1}\right)$.

$\mathrm{N}$ uptake by Seed yield was significantly fluctuated as affected by fertilization treatments and bacterial inoculation (Table 4). The highest values of $\mathrm{N}$ uptake by seed yield were observed with $100 \%$ compost manure as will as $75 \%$ Min $-\mathrm{N}+25 \%$ Leucaena residues under inoculated plants ,which relatively increased by about $18.9 \%$. over the fully chemical fertilized treatment $(100 \%$ urea- N. On the other hand, the lowest value was detected with the uninoculated plants treated with 50\% Min-N+50\% compost-N which relatively decreased by about $49.9 \%$ under those fully fertilized with urea.

Mean averages, despite of inoculation,-indicated the superiority of fully organic treated plant over those received $75 \%$ urea $+25 \%$ organic followed by $50 \%$ urea plus $50 \%$ organic the those of $25 \%$ urea plus $75 \%$ organic. The overall averages of organic sources revealed the superiority of quite manure over leuceana residues followed by compost treatment.

Positive effect of inoculation either applied solely or in combination with moderate amounts of chemical fertilizer on growth, seed yield and $\mathrm{N}$-uptake by snap bean was reported earlier by Mostafa and Zohair et al., (2014) under field conditions.

Table 4. Effect of fertilization treatments on $\mathrm{N}$ - uptake by seeds yield of common bean in the presence or absence of bacterial inoculation.

\begin{tabular}{|c|c|c|c|c|c|c|}
\hline \multirow{3}{*}{$\begin{array}{l}\text { Fertilization treatments } \\
\% \mathrm{Min}+\% \text { Org. }\end{array}$} & \multicolumn{6}{|c|}{ N-uptake by seeds (g/plot) } \\
\hline & \multicolumn{6}{|c|}{ Organic additives } \\
\hline & Inoc & untreated & Leucaena residues & Compost & Quite manure & Mean \\
\hline \multirow{2}{*}{$0+100$} & Inoc & - & 11.280 & 12.329 & 11.359 & 11.656 \\
\hline & Uninoc & - & 6.307 & 5.758 & 9.297 & 7.121 \\
\hline \multirow{3}{*}{$25+75$} & Mean & & 8.794 & 9.044 & 10.328 & \\
\hline & Inoc & - & 9.210 & 8.587 & 6.708 & 8.168 \\
\hline & Uninoc & - & 6.017 & 5.054 & 5.718 & 5.596 \\
\hline \multirow{3}{*}{$50+50$} & Mean & & 7.614 & 6.821 & 6.213 & \\
\hline & Inoc & - & 9.074 & 9.373 & 10.070 & 9.506 \\
\hline & Uninoc & - & 7.067 & 5.181 & 10.120 & 7.456 \\
\hline \multirow{3}{*}{$75+25$} & Mean & & 8.071 & 7.277 & 10.095 & \\
\hline & Inoc & - & 12.054 & 7.743 & 9.051 & 9.616 \\
\hline & Uninoc & - & 9.686 & 5.790 & 8.127 & 7.868 \\
\hline \multirow{3}{*}{$100+0$} & Mean & & 10.870 & 6.767 & 8.589 & \\
\hline & Inoc & 8.37 & & & & \\
\hline & Uninoc & 8.73 & & & & \\
\hline \multicolumn{7}{|l|}{ L.S.D at $5 \%$} \\
\hline Analysis of Variances & \multicolumn{3}{|c|}{ With and without Inoculation } & & & \\
\hline Nitrogen (A) : & & & 1.122 & & & \\
\hline Organic Materials (B) : & & & 0.958 & & & \\
\hline A $\mathrm{X} \quad \mathrm{B}:$ & & & 1.276 & & & \\
\hline
\end{tabular}

\section{Portions of nitrogen derived by seeds}

Nitrogen derived from fertilizer (Ndff), from air (Ndfa) and from soil+ organic (Ndfs + organic) by seeds ( $\mathrm{g}$ plot $^{-1}$ ) were markedly influenced by the additions of organic materials in mixture with mineral $\mathrm{N}$ fertilizer and alone with Rhizobium inoculation (Table 5).

It is clear that absolute values of Ndff, Ndfs + Ndfo and Ndfa were frequently affected by portions of chemical and organic additives whereas Ndff tended to increase with increasing $\mathrm{N}$ fertilizer rate. Adversely, $\mathrm{Ndfa}$ was negatively affected by increasing $\mathrm{N}$ rate. Highest value of Ndfa was recorded with application of compost at $75 \%$ in combination with $25 \%$ chemical fertilizer. It seems that organic additives enhanced the portions of Ndff and Ndfs. This holds true with and without Rhizobium inoculation. Nitrogen utilized from fertilizer were 6.712, 4.801 and $4.536 \mathrm{~g} \mathrm{plot}^{-1}$ observed in the plots received under with Rhizobium inoculation with organic materials mixed with mineral - $\mathrm{N}$ fertilizer additions, Leucaena residues, compost manure and quite manure at rates of $(25 \% \mathrm{~min}+$ $75 \%$ organic manure) respectively, in without Rhizobium inoculation, were $6.420,4.987,4.272$, and $3.094 \mathrm{~g} \mathrm{pot}^{-1}$ observed in the plots received rates of $(100 \% \mathrm{~min}+0$ organic $-\mathrm{N})$ and $(25 \% \mathrm{~min}+75 \%$ Leucaena residues $-\mathrm{N})$ ratios, $(25 \% \min +75 \%$ compost manure $-\mathrm{N})$ ratios, $(25 \%$ min $+75 \%$ quite manure $-\mathrm{N})$ ratios, respectively.

These findings were recently proved by Ismail et al., (2017), who found that, portion of nitrogen derived from fertilizer ( $\%$ Ndff), soil $(\% \mathrm{Ndfs}+\mathrm{Ndfo})$ and air $(\%$ Ndfa) by shoot and seeds of chickpea plants were markedly increased as influenced by the addition of organic manure mixed with mineral $\mathrm{N}$ fertilizer under bacterial inoculation.In the same time, Ndfa found to be enhanced by exogenous application of rhizobium inoculant comparing to the un-inoculated treatment(Bambara and Ndakidemi, 2010). 
Table 5. Nitrogen derived from fertilizer (Ndff), air (Ndfa) and soil+ organic (Ndfs+Ndfo) (g plot ${ }^{-1}$ ) by seeds as affected by organic additives mixed with chemical $N$ fertilizer with and without Rhizobium inoculation.

\begin{tabular}{|c|c|c|c|c|c|c|c|c|c|c|c|c|}
\hline \multirow{2}{*}{$\begin{array}{l}\begin{array}{l}\text { Fertilization } \\
\text { treatments }\end{array} \\
\end{array}$} & \multicolumn{12}{|c|}{ Organic additives } \\
\hline & & Untreat & & & Leuca & ena & & Com & ost & & Qui & \\
\hline \multirow{3}{*}{$\begin{array}{l}\text { Chem -N\% + } \\
\text { Org-N\% }\end{array}$} & \multicolumn{12}{|c|}{ Portions N derived by seeds $\left(\mathrm{g} \mathrm{plot}^{-1}\right)$} \\
\hline & \multicolumn{12}{|c|}{ Inoculated } \\
\hline & Ndff & Ndfa & Ndfs+Ndfo & Ndff & Ndfa & Ndfs+Ndfo & Ndff & Ndfa & Ndfs+Ndfo & Ndff & Ndfa & Ndfs+Ndfo \\
\hline $25 \%+75 \%$ & - & - & - & 4.444 & 1.580 & 3.187 & 3.700 & 1.500 & 3.400 & 2.584 & 1.244 & 2.880 \\
\hline $50 \%+50 \%$ & - & - & - & 4.751 & 1.152 & 3.171 & 4.300 & 1.432 & 3.640 & 4.801 & 1.444 & 4.127 \\
\hline $75 \%+25 \%$ & - & - & - & 6.712 & 0.723 & 4.615 & 4.536 & 0.693 & 2.514 & 4.230 & 0.835 & 3.937 \\
\hline \multirow{2}{*}{$100 \%+0 \%$} & 5.302 & 0.543 & 0.096 & - & - & - & - & - & - & - & - & - \\
\hline & \multicolumn{12}{|c|}{ Un-inoculated } \\
\hline $25 \%+75 \%$ & & - & & 3.241 & - & 2.775 & 2.504 & - & 2.550 & 3.055 & - & 2.699 \\
\hline $50 \%+50 \%$ & & - & & 3.623 & - & 3.444 & 2.690 & - & 2.491 & 5.298 & - & 4.822 \\
\hline $75 \%+25 \%$ & & - & & 4.987 & - & 3.899 & 3.094 & - & 2.696 & 4.272 & - & 3.855 \\
\hline $100 \%+0 \%$ & 6.420 & - & 2.310 & - & - & - & - & - & - & - & - & - \\
\hline
\end{tabular}

Nitrogen use efficiency (NUE\%)

Data listed in Table (6), revealed that nitrogen use efficiency (NUE\%) by seeds of common bean plants were markedly affected by the additions of organic-N mixed with chemical $\mathrm{N}$ fertilizer in different ratios with and without Rhizobium inoculation. the highest were $28.2 \%$

Table 6. Nitrogen use efficiency (NUE \%) by seeds as affected by different organic and chemical fertilizers in the presence or absence of Rhizobium inoculation.

\begin{tabular}{|c|c|c|c|c|c|}
\hline \multirow{2}{*}{$\begin{array}{l}\text { Fertilization treatments } \\
\text { Min\% + Org\% }\end{array}$} & \multicolumn{5}{|c|}{ Organic additives } \\
\hline & Inoculation & untreated & Leucaena residues & Compost & Quite manure \\
\hline \multirow{3}{*}{$25 \%$ Min $+75 \%$ Org } & Inocu & - & 25.8 & 24.0 & 28.2 \\
\hline & Uninocu & - & 16.8 & 14.1 & 16 \\
\hline & Mean & & 21.3 & 19.1 & 22.1 \\
\hline \multirow{2}{*}{$50 \% \operatorname{Min}+50 \%$ Org } & Inocu & - & 12.7 & 13.9 & 14.1 \\
\hline & Uninocu & - & 9.9 & 7.7 & 14.2 \\
\hline \multirow{4}{*}{$75 \%$ Min $+25 \%$ Org } & Mean & & 11.3 & 10.8 & 14.15 \\
\hline & Inocu & - & 11.2 & 7.2 & 8.4 \\
\hline & Uninocu & - & 8.4 & 5.4 & 7.6 \\
\hline & Mean & & 9.8 & 6.3 & 8.0 \\
\hline \multirow{2}{*}{$100 \% \operatorname{Min}+0 \%$ Org } & Inocu & 12.13 & - & - & - \\
\hline & Uninocu & 23.96 & - & - & - \\
\hline
\end{tabular}

The results revealed that both inoculation and low to moderate quantities of chemical fertilizer in combination with organic additives had enhanced the utilization of chemical-N source comparing to the full chemical fertilizer plants. Jatav, et al, (2016), demonstrated that, NUE was maximum (30 kg seeds $\mathrm{N}-1)$ under lower dose of $\mathrm{N}$ with Rhizobium (15kg N ha ${ }^{-1}+$ Rhizobium) as compared to only $15 \mathrm{~kg} \mathrm{~N} \mathrm{ha}^{-1}$ application without Rhizobium $(22.13 \mathrm{~kg}$ seeds $\mathrm{kg} \mathrm{N}^{-1}$ ). Inversely, increasing dose of $\mathrm{N}$ decreased the $\mathrm{N}$ use efficiency for all the treatments where in per cent decrease in NUE was more when only graded dose of N was applied as compared to its usage on Rhizobium inoculated seeds.

The superiority of one organic source over another was correlated to the amount of chemical nitrogen. On the other turn, the efficient use of chemical-N as affected by organic source is dependent on $\mathrm{N}$ rate.

\section{CONCLUSION}

Based on the present findings, we can conclude that leucaena residues and quite manure mixed with mineral $\mathrm{N}$ fertilizer in different ratios had a significant effect on the increase of seed yield and $\mathrm{N}$ content in plant either inoculated or not. Inoculated plants produced seed yield that is $9.82 \%$ higher than non-inoculated ones. Inoculated plants achieved relative increase in $\mathrm{N}$ uptake by seeds by about $21.83 \%$ over the non- inoculated ones. Considering the nitrogen derived from fertilizer, air, and soil by seeds, as well as nitrogen use efficiency (NUE\%) in the presence or absence of Rhizobium inoculation, organic type and chemical-N had a remarkable effect on NUE\%. Efficient and $16.8 \%$ observed in the plots received $25 \%$ chem $-\mathrm{N}+$ $75 \%$ Leucaena residues - N, while the lowest values recorded $5.9 \%$ and $6.1 \%$ observed in the plots fertilized with $100 \%$ Min - N with and without Rhizobium inoculation, respectively.

use of chemical-N was significantly enhanced by bacterial inoculation.

\section{REFERENCES}

Adeyeye .A.S ; A.O. Togun ; A.B. Olaniyan and W.B. Akanbi (2017) effect of fertilizer and rhizobium inoculation on growth and yield of soyabean variety (glycine max l.merrill).adv crop sci tech, 5:1

Akhter .Z; B.B.Pageni;N.Z. Lupwayi and P. M. Balasubramanian (2014) Biological nitrogen fixation and nifH gene expression in dry beans (Phaseolus vulgaris L.) Can J Plant Sci 94(2):203212.

Bambara. S and P. Ndakidemi (2010a) Phaseolus vulgaris response to Rhizobium inoculation, lime and molybdenum in selected low $\mathrm{pH}$ soil in western cape, South Africa. Afr J Agric Res 5:1804-1811

Bambara .S and P.A. Ndakidemi (2010b) Effects of Rhizobium inoculation,lime and molybdenum on nitrogen fixation of nodulated Phaseolus vulgaris $\mathrm{L}$. Afr J Microbiol Res 4:682-696

Bambara. Sylvie and Patrick .A. Ndakidemi (2010). Effects of Rhizobium innoculation, lime and molybdenum on nitrogen fixation of nodulated Phaseolus vulgaris L. African Journal of Microbiology Research 4: 682-696.

Belane. A.K and F.D. Dakora (2009) Measurement of N fixation in 30 cowpea (Vigna unguiculata L. Walp.) genotypes under field conditions in Ghana, using the $15 \mathrm{~N}$ natural abundance technique. Symbiosis 48(13):47-56. 
Brito. M. M. P., T .Muraoka,., and E.Silva (2011). Contribuiç̧o da fixaçっo biologica de nitrogenio, fertilizante nitrogenado e nitrogênio do solo no desenvolvimento de feij_o e caupi. Bragantia, 70(1), 206- 215.

Broughton.W.J., G.Hernandez.,M.Blair;SBeebe.,P .Gepts and J .Vanderleyden (2003) Beans (Phaseolus spp.) - model food legumes. Plant Soil 252:55128.

Centro Internacional de Agricultura Tropical (CIAT) (2001) Plant genetic resources: beans (Internet). Accessed 10 Mar 2015.

Feleafel.M.N and Z. M. Mirdad(2014). Influence of organic nitrogen on the snap bean grown in sandy soil. international journal of agriculture and biology issn print: 1560-8530; issn online: 1814-9596

Fukuda .M; F .Nagumo; S .Nakamura and S .Tobita (2012) Alternative fertilizer utilizing methods for sustaining low input agriculture. In: Soil fertility. InTech, Rijeka

Hungria. M; R.J. Campo and I.C. Mendes (2003) Benefits of inoculation of the common bean (Phaseolus vulgaris) crop with efficient and competitive Rhizobium tropici strains. Biol Fertil Soils 39:8893

IAEA, Vienna (2001). Use of isotope and radiation methods in soil and water management and crop nutrition. Manual. Training course series No. 14. IAEA, Vienna.

Ismail. M.M ; Ahmed A Moursy and A.E Mousa, (2017). Affect of organic and inorganic $\mathrm{n}$ fertilizer on growth and yield of chickpea (cicer arietinum 1.) grown on sandy soil using ${ }^{15} \mathrm{~N}$ tracer . Bangladesh J. Bot. 46(1): 155-161.

Jatav M.K; B.D Sharma;D.K Samadia and S.R Meena (2016). Efficacy of Rhizobium inoculation on graded $\mathrm{N}$ levels and net return from cluster bean seed production under hot arid regions Citation: EA: 61(3): 495-499.

Kellman. A.W; G.D. Hill and Mckenzie B.A (2005). Variability in nodulation of Phaseolus vulgaris $\mathrm{L}$. with different rhizobial strains. Agron NZ 35:57-65

lime and molybdenum on nitrogen fixation of nodulated Phaseolus vulgaris L. Afr J Microbiol Res 4:682696

Maina. F; J Kihara; U .Mokwunye (2011) Fighting poverty in subSaharan Africa: the multiple roles of legumes in integrated soil fertility management.

Mohale .K.C; Belane A.K and F.D. Dakora (2014) Symbiotic $\mathrm{N}$ nutrition, $\mathrm{C}$ assimilation, and plant water use efficiency in Bambara groundnut (Vigna subterranea L. Verdc) grown in farmers' fields in
South Africa, measured using ${ }^{15} \mathrm{~N}$ and $13 \mathrm{C}$ natural abundance. Biol Fertil Soils 50:307-319.

Moursy .A.A.A (2008). evaluation of selected composted organic sources on potato plant grown in sandy soil using nuclear technique M.Sc. Thesis, Fac. of Agric Moshtohor, Benha Univ., Egypt.

Mahrous .N.M;S. A Safina; H. H. Abo Taleb and S. M. E. El-Behlak, (2015). Integrated Use of Organic, Inorganic and Bio Fertilizers on Yield and Quality of Two Peanut (Arachis hypogaea L.) Cultivars Grown in a Sandy Saline Soil. American-Eurasian J. Agric. \& Environ. Sci., 15 (6): 1067-1074.

Naab. J.B; S.B.M Chimphango and F.D. Dakora (2009) Nfixation in cowpea. Symbiosis 48(1-3):37 plants grown in farmers' fields in the upper west region of Ghana, measured using $15 \mathrm{~N}$ natural abundance -46 .

Ngetich .F.K; C.A Shisanya ; J Mugwe; M Mucheru-Muna and D Mugendi (2012) The potential of organic and inorganic nutrient sources in Sub-Saharan African crop farming systems. In: Soil fertility improvement and integrated nutrient management-a global perspective. InTech, Rijeka

Nyemba .R.C and F.D Dakora (2010) Evaluating Nfixation by food grain legumes in farmers' fields in three agro-ecological zones of Zambia using ${ }^{15} \mathrm{~N}$ natural abundance. Biol Fertil Soils 46(5):461-470.

Pule-Meulenberg F; A.K Belane;T .Krasova-Wade and F.D. Dakora (2010) Symbiotic functioning and bradyrhizobial biodiversity of cowpea (Vigna unguiculata L. Walp.) in Africa. BMC Microbiol 10(1):89.

SAS (1995). Statistical Analysis System user's Guide, Version 5, Cray, CN.

Soares, A. L. L; P. A .Ferreira; J. P. A. R Pereira; H. M. M Vale; A. S Lima; M. J. B Andrade., and F. M. S. Moreira (2006). Eficiência agronômica de rizobios selecionados e diversidade de populaçoes natives nodulsferas em Perdoes (MG) (II): feijoeiro. Revista Brasileira de Ciência do Solo, 30(5), 803811.

Souza E. F. C., R. P Soratto and F. A. Pagani (2011). Aplicaçəo de nitrogênio e inoculaçৎo com rizobio em feijoeiro cultivado aps milho consorciado com braquiuria. Pesquisa Agropecu tria Brasileira, 46(4), 370-377.

Sprent J.I, D.W Odee and F.D. Dakora (2010) African legumes - a vital but under-utilised resource. J Exp Bot 61(5):1257-1265.

Tabaro. A .(2014) Evaluation of effectiveness of rhizobia isolates from Rwandan soils on common bean (Phaseolus vulgaris L.). MSc. Dissertation, University of Nairobi

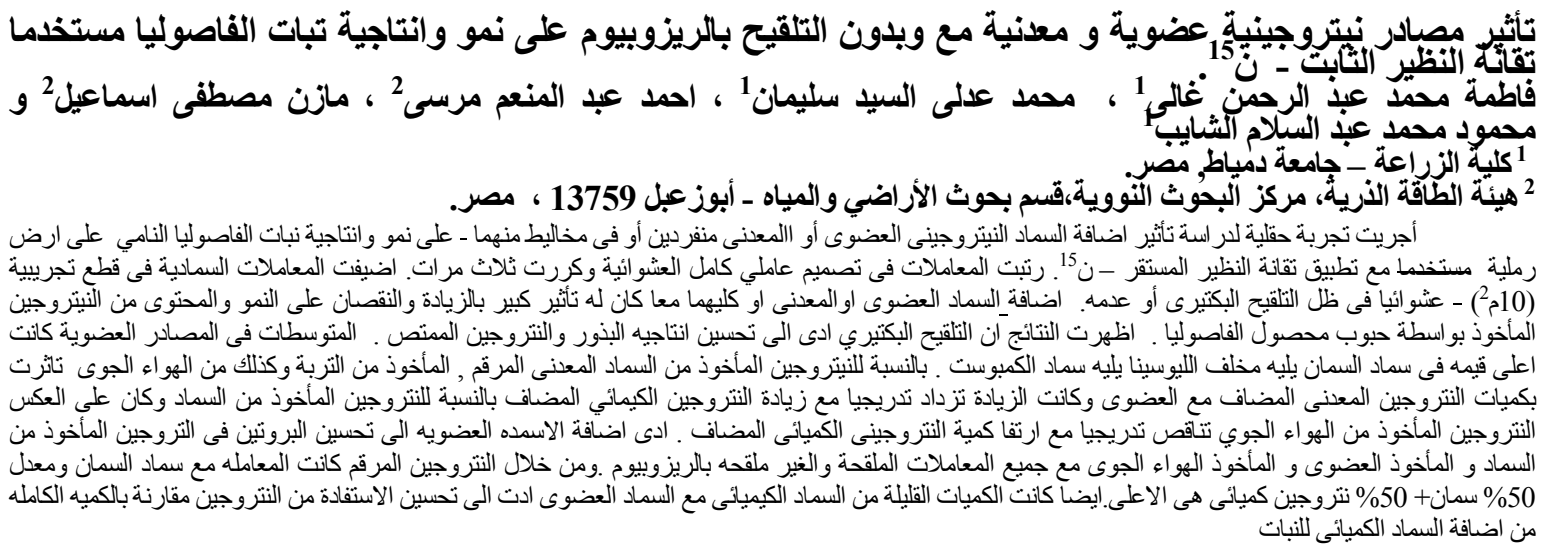

